Article

\title{
Study on the Low-Temperature Oxidation Law in the Co-Mining Face of Coal and Oil Shale in a Goaf-A Case Study in the Liangjia Coal Mine, China
}

\author{
Gang Wang ${ }^{1,2,3, *}$, Yue Wang ${ }^{2}$, Lulu Sun ${ }^{2}$, Xiang Song ${ }^{2}$, Qiqi Liu ${ }^{2}$, Hao Xu ${ }^{2}$ and Wenzhou Du ${ }^{2}$ \\ 1 Mine Disaster Prevention and Control-Ministry of State Key Laboratory Breeding Base, \\ Shandong University of Science and Technology, Qingdao 266590, China \\ 2 College of Mining and Safety Engineering, Shandong University of Science and Technology, \\ Qingdao 266590, China; sdkdwangyue@163.com (Y.W.); sunsdust@126.com (L.S.); \\ 15764250761@163.com (X.S.); 15764227280@139.com (Q.L.); 15764250244@163.com (H.X.); \\ duwenzhou-01@163.com (W.D.) \\ 3 Hebei State Key Laboratory of Mine Disaster Prevention, North China Institute of Science and Technology, \\ Beijing 101601, China \\ * Correspondence: Gang.Wang@sdust.edu.cn; Tel.: +86-0532-80698100
}

Received: 18 November 2017; Accepted: 9 January 2018; Published: 11 January 2018

\begin{abstract}
The low-temperature oxidation law of coal and rock mass is the basis to study spontaneous combustion in goafs. In this paper, the low-temperature oxidation laws of coal, oil shale, and mixtures of coal and oil shale were studied by using laboratory programmed heating experiments combined with a field beam tube monitoring system. The results from the programmed heating experiments showed that the heat released from oil shale was less than that from coal. Coal had a lower carbon monoxide (CO)-producing temperature than oil shale, and the mixture showed obvious inhibiting effects on CO production with an average CO concentration of about $38 \%$ of that for coal. Index gases were selected in different stages to determine the critical turning point temperature for each stage. The field beam tube monitoring system showed that the temperature field of the $1105 \mathrm{co}$-mining face of coal and oil shale in the goaf of the Liangjia Coal Mine presented a ladder-like distribution, and $\mathrm{CO}$ concentration was the highest for coal and lower for the mixture of coal and oil shale, indicating that the mixture of coal with oil shale had an inhibiting effect on CO production, consistent with the results from the programmed heating experiments.
\end{abstract}

Keywords: coal and oil shale; low-temperature oxidation; programmed heating; goaf; beam tube monitoring system

\section{Introduction}

Mine fires are among the most dangerous disasters that affect a safe production in mines. After mining the working face, the empty space of the mined coal is defined as goaf, where residual coal is continuously oxidized in the goaf, with flammable gas released and temperature increased, which can potentially lead to fire in the goaf. According to studies, more than $60 \%$ of mine fires in China are caused by the spontaneous combustion of residual coal in goafs [1,2]. The prevention of fire in goafs is of great significance for a safe production in mines. Oil shale is a fine-grained sedimentary rock containing large quantities of organic matter capable of yielding oil upon retorting, with an oil content of 3.5-30\%. When heated above $500{ }^{\circ} \mathrm{C}$ in an oxygen-poor environment, it can yield shale oil, which has a significant role in mitigating the pressure of oil crisis as an alternative to oil energy in some industrial production [3]. Oil shale is commonly associated with coal, and both coal and oil shale can be slowly oxidized in goafs resulting in a temperature increase and flammable gases release. Therefore, the risk of spontaneous combustion exists at the co-mining face of coal and oil shale in 
goafs [4]. Meanwhile, when coal and oil shale are mixed, their oxidation behaviors will be mutually affected by their physical and chemical properties and will thus change, becoming different from those of coal or oil shale alone. Therefore, the study of the oxidation law in the co-mining face of coal and oil shale is of great significance to guiding a safe production in coal and oil shale mines.

There is a long history of coal utilization, and the oxidation characteristics of coal have been studied for a long time, while oil shale research started to develop later. Regarding the oxidation characteristics of oil shale, scholars have mainly paid attention to the gas and temperature during the pyrolysis process [5]. Jiang et al. studied the influence of hydrothermal pretreatment on the distribution of pyrolysis product and oil characteristics [6]. Mohammad Al-Harahsheh et al. investigated the effects of the mineral content in oil shale on pyrolysis [7]. Miao et al. measured the volatile components of Daqing oil shale using a thermogravimetric analysis, examined the impact of the temperature rise rate and of the final temperature of pyrolysis characteristic of the oil shale, and found that final temperature of pyrolysis was the most important factor influencing the volatile content: the higher the final temperature of pyrolysis, the higher the volatile content [8]. A. Mumtaz Tugluhan divided the oxidation reaction into three stages based on the variation law of $\mathrm{CO}$, oxygen, and carbon dioxide $\left(\mathrm{CO}_{2}\right)$ of Turkey oil shale under the air flow rate of $1.5 \mathrm{~L} / \mathrm{min}$ : namely, low temperature stage, transition stage, and high temperature stage [9]. Li et al. studied the thermodynamic properties and gas compositions of bituminous coal and lignite during the co-heating of oil shale using the TG-FTIR coupling technique (Nicolet ${ }^{\mathrm{TM}}$ iS $^{\mathrm{TM}} 10$ FT-IR, Thermo Fisher Scientific, Shanghai, China) and found that the thermodynamic properties of oil shale were similar to those of bituminous coal at the stage of devolatilization [10]. Furthermore, they analyzed the influence of the oil shale ratio on the volatile components of samples throughout the experiments.

For the exploration of the oxidation characteristics of residual coal in goafs, field experiments and laboratory experiments are mainly adopted. Programmed heating is an experimental method in which the ambient temperature is controlled through constant heat transfer to increase it at a constant rate under specific initial temperature conditions. With the advantages of its good experiment process continuity as well as its simple and quick operation, it has been widely used in the spontaneous combustion of coal, including index gas tests [11,12] and cross-point temperature tests [13,14]. Qin et al. studied the oxygen consumption rate of pulverized coal in different particle sizes using a self-developed CSC-B2 programmed heating system (China University of Mining and Technology (Beijing), Beijing, China) based on the oxygen concentration at the inlet and outlet of the vessel, and obtained an empirical formula of oxygen consumption [15]. Kucuk et al. investigated the effects of different coal particle sizes, coal water content, and air humidity on the spontaneous combustion of coal using a programmed temperature-raising device [16]. Tan et al. analyzed the characteristics of the gases derived from the spontaneous combustion of coal samples of varying degrees of metamorphism at different temperature stages, using a programmed heating device, and studied the corresponding relation between the index gas and the characteristic temperature range [17]. In a real goaf, as the temperature rises, gas sequestration in coals changes, while coal's adsorption ability, gas permeability, and gas sorption affect gas release by coal oxidation $[18,19]$. The change of gas production in a goaf will also affect the adsorption and desorption of the coal matrix, resulting in the expansion and contraction of the coal skeleton and in changes in coal's internal permeability $[20,21]$, thereby changing coal's oxidation characteristics. The fracture characteristics and geometrical characteristics of the field also affect the oxidation of coal [22]. Because the existing simulation and theoretical derivation are not enough to directly indicate the oxidation state of coal in a goaf, the simplest method is to directly observe the temperature and gas variation in a goaf. In field experiments, the method of laying a beam tube monitoring system is one of the most commonly used means to monitor the oxidation of coal and rock mass in goafs. The data of temperature, $\mathrm{CO}$, oxygen, and other gases in a goaf obtained by the beam tube monitoring system can be used for the determination of coal and rock mass oxidation and the division of three zones [23-25]. 
The scholars mentioned above studied the pyrolysis and the oxidation temperature rise properties of oil shale and coal. However, when there is a co-mining face of coal and oil shale, the interaction between coal and oil shale causes considerable changes in heat liberation and gas concentration. As for the results of the direct interaction between coal and oil shale, scholars have not carried out in-depth research. Therefore, the research described in this paper aims mainly to (1) determine the changes of temperature and gas concentration of coal, oil shale, and mixtures of coal and oil shale; (2) measure the temperature and gas composition in goafs on the field using a beam tube monitoring system and (3) eventually obtain the spontaneous combustion rules of coal and oil shale in goafs related to low-temperature oxidation. Our laboratory results and on-site monitoring data provide technical support for fire prevention and extinguishment in the co-mining face of coal and oil shale in goafs.

\section{Experiment Device and Process}

\subsection{Preparation of the Experimenalt Samples}

The oil shale and coal wall just exposed at the 1105 co-mining face of coal and oil shale in the Liangjia Mine was selected. A total of six fresh samples were collected at the upper, middle, and lower heights, sealed on-site in sealing bags, and sent to the laboratory. When preparing the samples, the surface oxide layers were first striped, a certain amount of samples were quickly crushed to prevent exposure to the air at room temperature, sieved out with a particle size of $0.18-0.38 \mathrm{~mm}$, sealed in sealing bags, placed in a closed container covered with desiccant (we made sure that the desiccant was not in contact with the samples), dried for $5 \mathrm{~h}$, and stored at room temperature.

\subsection{Programmed Heating Experiment Device and Process}

The experiment device was composed of three parts: (a) laboratory gas source, (b) programmable oven, and (c) gas chromatograph, as shown in Figure 1. The laboratory gas source was the QPT-300G Nitrogen Hydrogen Air Generator from Shanghai Lingxi Instrument Co. Ltd. (Shanghai, China), in which the air output part consisted of an oil-free compressor and a stainless steel gas tank, and used a secondary regulator and a three-stage filtration technology to achieve gas stability, high precision output, as well as perfect automatic drainage protection measures. The air output pressure was maintained at $0.4 \mathrm{MPa}$ with an adjustable range of 0-0.5 MPa. The output nitrogen and hydrogen had a purity of $>99.999 \%$. During the experiments, the gas chromatograph was first calibrated with a standard gas, and air was introduced to conduct the experiment. The programmable oven was a ZRJ-2000 coal spontaneous tendency detector from Beijing Sida Hengtong Technology Co. Ltd. (Beijing, China). It was supplied with a heater of $1200 \mathrm{~W}$, whose heating power was controlled by a computer program, and a built-in fan of $1400 \mathrm{r} / \mathrm{min}$ to ensure a uniform air temperature in the furnace. The temperature control precision was $\pm 0.1^{\circ} \mathrm{C}$. The sample tank was a cylindrical container made of brass material and had an inner diameter of $43 \mathrm{~mm}$, an outer diameter of $48 \mathrm{~mm}$, an inner height of $100 \mathrm{~mm}$, and an outer height of $105 \mathrm{~mm}$. The actual sample height was about $70 \mathrm{~mm}$. The bottom and top of the sample tank were provided with a gas inlet and outlet, respectively. The small hole in the center of the sample tank was used to install the temperature sensor contact. The top of the contact was located at the geometric center of the sample tank. The sample tank was made of a polytetrafluoroethylene sealing material, which can withstand high temperatures above $350{ }^{\circ} \mathrm{C}$. Inside, the sample tank was equipped with a precision platinum resistance temperature sensor to monitor the sample temperature and the oven temperature. The gases were analyzed using a GC9790 Gas Chromatograph manufactured by Fuli instruments Co. Ltd. (Taizhou, China), which can detect a gas concentration in the range of $8-399^{\circ} \mathrm{C}$, meeting the requirements of this experiment. Gas concentrations calculated by the gas chromatograph are usually infinite non-cyclic fractions; two digits after the decimal point were retained as the significant figures. 


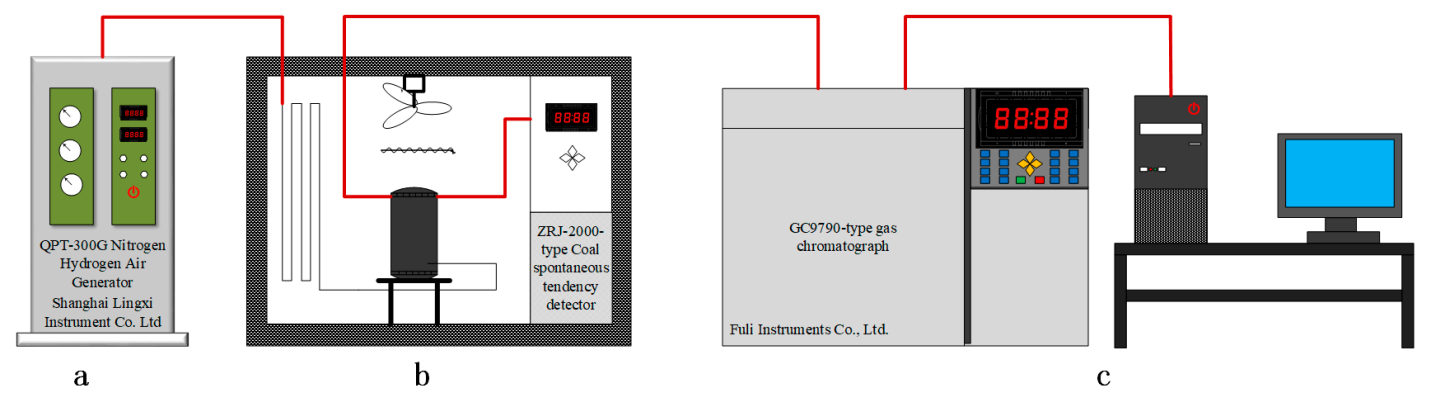

Figure 1. Programmed heating system.

The programmed heating experiments were conducted for coal, oil shale, and mixed coal and oil shale with a coal to oil shale ratio of 1:0.22 (that is the ratio of coal to oil shale in the goaf in the field experiments) to study the variations of the behaviors of temperature and gas concentration during programmed heating. In the experiment, $40 \mathrm{~g}$ of each sample was placed into the sample tank and covered with a layer of asbestos to filter the air flow and prevent clogging of the gas line. A previous study showed that the reaction rate rises by an order of magnitude for every $10{ }^{\circ} \mathrm{C}$ rise in temperature [26]. Consequently, within the allowable temperature range, the same heating rate for different sets of experiments must be strictly guaranteed. In agreement with relevant literature, the heating rate for this experiment was set at $0.5^{\circ} \mathrm{C} / \mathrm{min}$, and the gas composition and concentration were analyzed every $20 \mathrm{~min}$, with the air supply rate set at $50 \mathrm{~mL} / \mathrm{min}[15,17]$. The gas flowed into the gas chromatograph, and the data were output to a computer to be automatically saved.

\subsection{Analysis of the Experimental Results}

Based on the experimental results, as shown in Tables 1 and 2, the relationships between temperature and time, as well as between gas concentration and temperature were mainly selected for analysis. In field practice, the index of the gas concentration ratio is usually selected for analysis to eliminate the influence of the air flow rate on concentration [27]. Similar to previous research results, the relationships temperature-time, $\mathrm{CO}$-temperature, $\mathrm{CO} / \mathrm{CO}_{2}$-temperature, $\mathrm{C}_{2} \mathrm{H}_{4} / \mathrm{C}_{2} \mathrm{H}_{6}$-temperature and $\mathrm{C}_{3} \mathrm{H}_{8} / \mathrm{C}_{2} \mathrm{H}_{6}$-temperature were selected for analysis in this paper $[28,29]$.

Table 1. Programmed heating experimental results $\left(\mathrm{CO}, \mathrm{CO} / \mathrm{CO}_{2}\right)$.

\begin{tabular}{ccccccc}
\hline \multirow{2}{*}{ Temperature/ ${ }^{\circ} \mathbf{C}$} & \multicolumn{3}{c}{ CO/ppm } & \multicolumn{3}{c}{ CO/CO } \\
\cline { 2 - 6 } & Coal & Oil Shale & Mixture & Coal & Oil Shale & Mixture \\
\hline 30.00 & 5.42 & 0.00 & 0.00 & 0.02 & - & - \\
40.00 & 6.38 & 0.00 & 1.48 & 0.02 & - & 0.01 \\
50.00 & 24.84 & 0.00 & 8.46 & 0.06 & - & 0.04 \\
60.00 & 52.85 & 24.06 & 14.58 & 0.09 & 0.05 & 0.05 \\
70.00 & 95.58 & 42.37 & 28.86 & 0.10 & 0.05 & 0.06 \\
80.00 & 165.22 & 64.22 & 45.09 & 0.11 & 0.07 & 0.08 \\
90.00 & 223.05 & 107.47 & 48.54 & 0.11 & 0.09 & 0.08 \\
100.00 & 309.53 & 189.43 & 74.16 & 0.11 & 0.13 & 0.11 \\
110.00 & 408.72 & 315.58 & 121.09 & 0.12 & 0.17 & 0.14 \\
120.00 & 432.16 & 579.15 & 206.00 & 0.15 & 0.20 & 0.17 \\
130.00 & 1215.16 & 1120.26 & 486.89 & 0.17 & 0.24 & 0.27 \\
140.00 & 2560.37 & 2006.52 & 1006.25 & 0.20 & 0.26 & 0.24 \\
150.00 & 6530.46 & 4866.66 & 1910.92 & 0.26 & 0.28 & 0.27 \\
160.00 & 9150.12 & 8193.66 & 2611.71 & 0.29 & 0.31 & 0.27 \\
170.00 & 9956.08 & $14,095.58$ & 3620.90 & 0.29 & 0.31 & 0.30 \\
180.00 & $11,161.43$ & $14,765.70$ & 4570.72 & 0.30 & 0.31 & 0.31 \\
190.00 & $12,505.99$ & $15,730.71$ & 5277.36 & 0.30 & 0.31 & 0.33 \\
200.00 & $13,644.21$ & $16,557.66$ & 5636.88 & 0.31 & 0.30 & 0.34 \\
\hline
\end{tabular}


Table 2. Programmed heating experiment results $\left(\mathrm{C}_{2} \mathrm{H}_{4} / \mathrm{C}_{2} \mathrm{H}_{6}, \mathrm{C}_{3} \mathrm{H}_{8} / \mathrm{C}_{2} \mathrm{H}_{6}\right)$.

\begin{tabular}{ccccccc}
\hline \multirow{2}{*}{ Temperature $/{ }^{\circ} \mathbf{C}$} & \multicolumn{3}{c}{$\mathrm{C}_{\mathbf{2}} \mathbf{H}_{\mathbf{4}} / \mathbf{C}_{\mathbf{2}} \mathbf{H}_{\mathbf{6}}$} & \multicolumn{3}{c}{$\mathrm{C}_{\mathbf{3}} \mathbf{H}_{\mathbf{8}} / \mathbf{C}_{\mathbf{2}} \mathbf{H}_{\mathbf{6}}$} \\
\cline { 2 - 7 } & Coal & Oil Shale & Mixture & Coal & Oil Shale & Mixture \\
\hline 110.00 & - & 0.00 & - & - & 0.00 & - \\
120.00 & 0.00 & 0.85 & 0.00 & 0.00 & 0.00 & 0.00 \\
130.00 & 0.51 & 0.82 & 0.30 & 0.00 & 0.66 & 0.00 \\
140.00 & 0.56 & 0.67 & 0.25 & 1.01 & 0.77 & 0.40 \\
150.00 & 0.35 & 0.50 & 0.35 & 0.68 & 0.67 & 0.52 \\
160.00 & 0.27 & 0.36 & 0.28 & 0.65 & 0.70 & 0.41 \\
170.00 & 0.26 & 0.29 & 0.32 & 0.70 & 0.73 & 0.56 \\
180.00 & 0.24 & 0.18 & 0.31 & 0.65 & 0.59 & 0.62 \\
190.00 & 0.24 & 0.31 & 0.31 & 0.63 & 0.74 & 0.62 \\
200.00 & 0.22 & 0.30 & 0.31 & 0.63 & 0.75 & 0.62 \\
\hline
\end{tabular}

\subsubsection{Temperature}

As shown in Figure 2, the sample temperature changed with time in the programmed heating experiment. The temperature of the programmable oven increased linearly with time (the slope was the set programmed heating rate of $0.5^{\circ} \mathrm{C} / \mathrm{min}$ ). At the initial stage between $0-180 \mathrm{~min}$, the three samples were at the slow oxidation stage with a temperature rise rate of $<0.5^{\circ} \mathrm{C} / \mathrm{min}$. The heating rate was the greatest for coal, followed by the mixture, and was the smallest for oil shale. However, the difference in heating rate between coal and the mixture was very subtle, and their rates of increase were basically the same, indicating that at the initial stage of mixture oxidation, the heat release was mainly from coal and barely from oil shale. When the ambient temperature exceeded $70{ }^{\circ} \mathrm{C}$, the temperature rise rate of oil shale decreased first. After $100 \mathrm{~min}$, the temperature rise rate fell for all three samples, and oil shale had the lowest temperature rise rate and the least oxidation heat release. With oxidation rate increasing, the curve of the temperature change for oil shale became steeper at $180 \mathrm{~min}$, and heat was released from $180 \mathrm{~min}$ to $270 \mathrm{~min}$. By contrast, the temperature change curves of coal and mixture samples became steeper at $220 \mathrm{~min}$, lagging behind that of oil shale, and heat was released from $220 \mathrm{~min}$ to $300 \mathrm{~min}$, with less heat released than from oil shale.

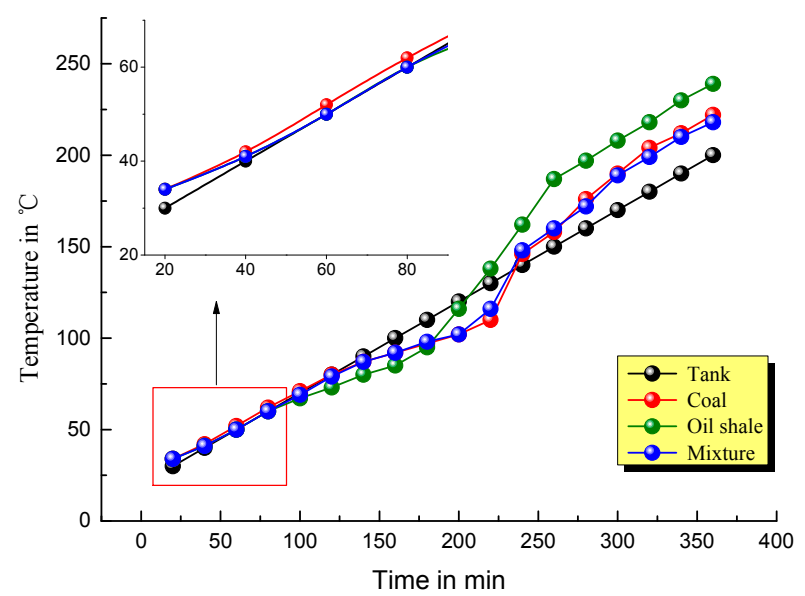

Figure 2. Relationship between temperature and time in the programmed heating experiment.

The temperature at which the sample becomes hotter than the oven is referred to as the cross-point temperature [30]. After exceeding the cross-point temperature, the sample temperature rises rapidly to reach the ignition point, and the coal oxidation in the goaf could become difficult to control. The cross-point temperature of each sample could be calculated from the curve, and was $123.3^{\circ} \mathrm{C}$ for oil shale, $136.4{ }^{\circ} \mathrm{C}$ for the mixture of coal and oil shale, and $137.7^{\circ} \mathrm{C}$ for coal. At the later stage 
of the experiment, the temperature rise trends of the three samples were consistent with the slowed temperature rise rate, and were basically maintained at $0.5{ }^{\circ} \mathrm{C} / \mathrm{min}$. After $180 \mathrm{~min}$, oil shale showed a significantly greater temperature rise than coal or mixture, and the highest final heat release.

In summary, the temperature rise curve of the three samples after oxidation showed the following characteristics. At the initial oxidation stage, the temperature of the three samples increased slowly with an increase rate smaller than the set value of the programmed heating rate, and heat release decreased in the order from coal, to mixture of coal and oil shale, and to oil shale. With the increase of the ambient temperature, according to both the turning point of the temperature rise rate and the cross-point temperature, the temperature increased in the order from oil shale, to mixture of coal and oil shale, to coal. At the end of the low temperature oxidation stage, the heat release was the highest for oil shale, followed by coal and finally the mixture, indicating that, above $100{ }^{\circ} \mathrm{C}$, the mixture of coal and oil shale had slight inhibiting effects on heat release.

\subsubsection{Gas Products}

Figure 3 shows the curve of the relationship between $\mathrm{CO}$ concentration and temperature. At $30{ }^{\circ} \mathrm{C}$, a small amount of $\mathrm{CO}$ was detected in coal, and, at $40{ }^{\circ} \mathrm{C}, \mathrm{CO}$ came from the mixture of coal and oil shale. At $60^{\circ} \mathrm{C}, \mathrm{CO}$ was also detected in oil shale samples, but the initial $\mathrm{CO}$ concentrations of the three samples were less than $30.00 \mathrm{ppm}$, with a low growth rate. After $70^{\circ} \mathrm{C}$, the concentration growth rate of $\mathrm{CO}$ produced from coal and oil shale increased with the temperature, and the concentration of $\mathrm{CO}$ began to increase slowly. At $120^{\circ} \mathrm{C}$, the oxidation of coal and oil shale increased, thus the $\mathrm{CO}$ concentration curve rose steeply, and CO concentration increased dramatically, $>10,000.00 \mathrm{ppm}$. When the coal sample was heated to $160^{\circ} \mathrm{C}$ and the oil shale sample to $170{ }^{\circ} \mathrm{C}, \mathrm{CO}$ concentration showed a slowed increase trend with the increase of the temperature, but still remained at a high level. $\mathrm{CO}$ concentration from oil shale grew more rapidly, resulting in the highest $\mathrm{CO}$ concentration. The concentration increase rate of $\mathrm{CO}$ from the mixture of coal and oil shale rose to $120{ }^{\circ} \mathrm{C}$ and decreased to $<6000.00 \mathrm{ppm}$ at $200{ }^{\circ} \mathrm{C}$, which was obviously lower than that from coal and oil shale.

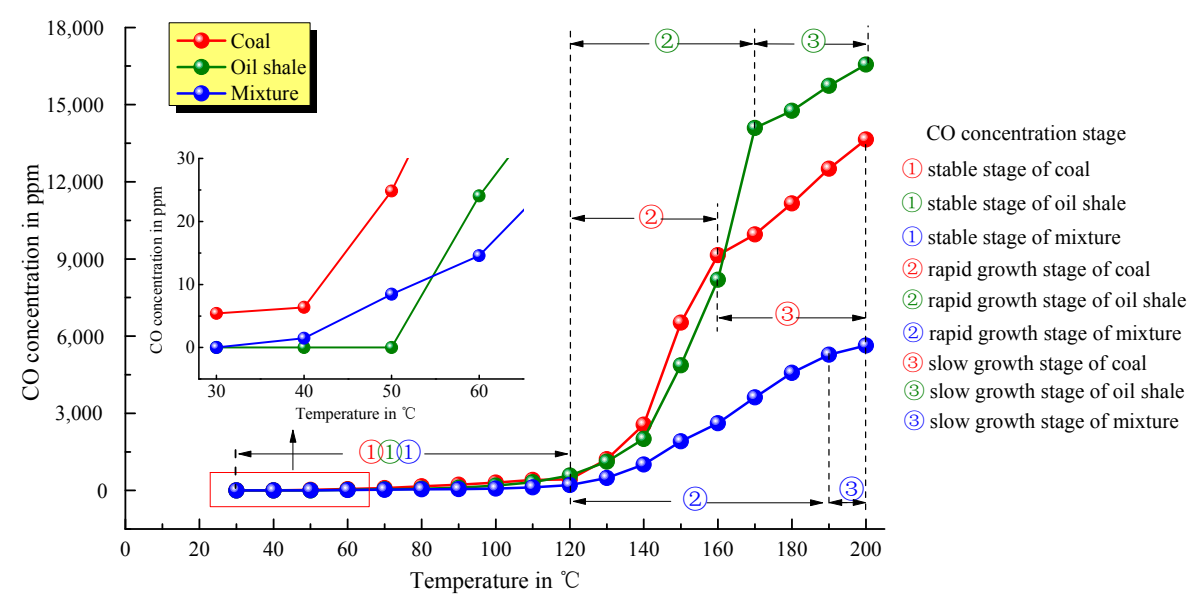

Figure 3. Relationship between $\mathrm{CO}$ concentration and temperature.

In conclusion, the $\mathrm{CO}$ concentration curve showed the following characteristics in the programmed heating experiment. The curves of the three samples can be divided into three stages, namely, stable stage, rapid growth stage, and slow growth stage, as shown in Table 3. At the stable stage, the temperature interval of the three samples was the same, and the amount of $\mathrm{CO}$ concentration was small. CO was first produced from coal, and its concentration was slightly higher than that from oil shale. The three samples entered then the rapid growth stage at the same time, and a large amount of $\mathrm{CO}$ was produced rapidly. The oxidation rate of coal, oil shale, and mixture samples fell at $160{ }^{\circ} \mathrm{C}$, $170^{\circ} \mathrm{C}$, and $190^{\circ} \mathrm{C}$, respectively, entering the slow growth stage. In contrast with coal and oil shale, the 
oxidation rate of the mixture fell at $190^{\circ} \mathrm{C}$, and the $\mathrm{CO}$ production rate decreased from $70.67 \mathrm{ppm}$ to $35.95 \mathrm{ppm}$. Therefore, we believe that $190{ }^{\circ} \mathrm{C}$ was the temperature point at which the mixture entered the slow growth stage. At the slow growth stage, the $\mathrm{CO}$ production rate of the mixture tended to be stabilized, while that of coal and oil shale samples continued to increase. At the rapid growth stage and the slow oxidation stage, the ratio of the average $\mathrm{CO}$ production of the mixture sample to the coal sample was $38 \%$, and that of the mixture sample to the oil shale sample was $36 \%$, indicating that mixing oil shale and coal could inhibit the $\mathrm{CO}$ production rate and decrease the total $\mathrm{CO}$ amount during oxidation.

Table 3. Three sample stages with respect to CO concentration.

\begin{tabular}{ccccc}
\hline Index & Sample & Stable Stage $/{ }^{\circ} \mathbf{C}$ & Rapid Growth Stage $/{ }^{\circ} \mathbf{C}$ & Slow Growth Stage $/{ }^{\circ} \mathbf{C}$ \\
\hline \multirow{3}{*}{ CO } & Coal & $30-120$ & $120-160$ & $160-200$ \\
\cline { 2 - 5 } & Oil shale & $30-120$ & $120-170$ & $170-200$ \\
\cline { 2 - 5 } & Mixture & $30-120$ & $120-190$ & $190-200$ \\
\hline
\end{tabular}

\subsubsection{Ratio Indexes for Different Samples}

Figure 4 shows the relationship between the $\mathrm{CO} / \mathrm{CO}_{2}$ ratio and the box temperature. The $\mathrm{CO} / \mathrm{CO}_{2}$ ratio for different samples increased continuously with the temperature. At $30^{\circ} \mathrm{C}$, the ratio could be obtained already for both coal and mixture samples, but not for oil shale. After $60^{\circ} \mathrm{C}, \mathrm{CO}$ was produced from oil shale, and the ratio of $\mathrm{CO} / \mathrm{CO}_{2}$ could be obtained. Based on the trend of $\mathrm{CO} / \mathrm{CO}_{2}$, the curves of the three samples could be divided into three stages, as shown in Table 4 . At $30-40{ }^{\circ} \mathrm{C}$ and $60-100{ }^{\circ} \mathrm{C}$, all samples were at the slow growth stage, while at $40-60^{\circ} \mathrm{C}$ and $100-160^{\circ} \mathrm{C}$, all samples were at the rapid growth stage. The slow stage of oil shale and mixture terminated at $80^{\circ} \mathrm{C}$ and $90^{\circ} \mathrm{C}$, respectively. At this stage, the ratio of $\mathrm{CO} / \mathrm{CO}_{2}$ was the highest for coal, followed by the mixture, and the lowest for oil shale. After entering the rapid growth stage, the $\mathrm{CO} / \mathrm{CO}_{2}$ ratio for oil shale and mixture increased rapidly and was the highest for oil shale, followed, in turn, by the mixture and coal. At $130{ }^{\circ} \mathrm{C}$, the $\mathrm{CO} / \mathrm{CO}_{2}$ ratio of the mixture was 0.2674323 . This anomalous surge in $\mathrm{CO} / \mathrm{CO}_{2}$ was caused by a dramatically low $\mathrm{CO}_{2}$ production due to an insufficient reaction of a large amount of $\mathrm{CO}$ produced from the mixture with oxygen. After that, the $\mathrm{CO} / \mathrm{CO}_{2}$ curve of the coal and oil shale samples entered the stable stage, while that of the mixture sample was still at the rapid growth stage. After the mixture was heated over $190{ }^{\circ} \mathrm{C}$, the $\mathrm{CO} / \mathrm{CO}_{2}$ curve entered the stable stage. When all the three samples were at the stable stage, the $\mathrm{CO} / \mathrm{CO}_{2}$ ratio stabilized at 0.3 for coal and oil shale, and at 0.35 for the mixture.

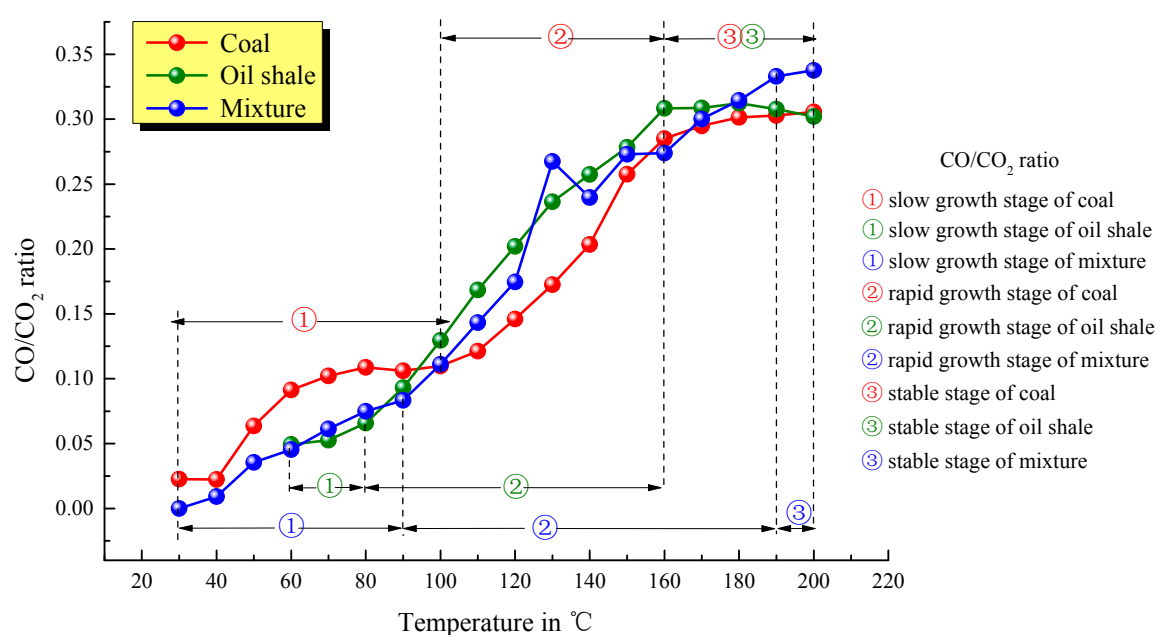

Figure 4. Relationship between the $\mathrm{CO} / \mathrm{CO}_{2}$ ratio and temperature for the experimental samples. 
Table 4. Three sample stages divided with respect to the $\mathrm{CO} / \mathrm{CO}_{2}$ ratio.

\begin{tabular}{ccccc}
\hline Index & Sample & Slow Growth Stage $/{ }^{\circ} \mathbf{C}$ & Rapid Growth Stage $/{ }^{\circ} \mathbf{C}$ & Stable Stage $/{ }^{\circ} \mathbf{C}$ \\
\hline \multirow{3}{*}{$\mathrm{CO} / \mathrm{CO}_{2}$} & Coal & $30-40$ & $40-60$ & $160-200$ \\
\cline { 2 - 5 } & & $60-100$ & $100-160$ & $160-200$ \\
\cline { 2 - 5 } & Oil shale & $60-80$ & $80-160$ & $190-200$ \\
\hline
\end{tabular}

Figure 5 shows the relationship curve between $\mathrm{C}_{2} \mathrm{H}_{4} / \mathrm{C}_{2} \mathrm{H}_{6}$ and temperature for the experimental samples. The curve could be mainly divided into three stages, as shown in Table 5. The $\mathrm{C}_{2} \mathrm{H}_{4} / \mathrm{C}_{2} \mathrm{H}_{6}$ ratio of the three samples first showed a rapid growth stage. At this time, the coal sample reached $140{ }^{\circ} \mathrm{C}$, the oil shale reached $120^{\circ} \mathrm{C}$, and the mixture reached $150{ }^{\circ} \mathrm{C}$. The $\mathrm{C}_{2} \mathrm{H}_{4} / \mathrm{C}_{2} \mathrm{H}_{6}$ ratio was the highest for oil shale, followed by coal and then the mixture. After that, the $\mathrm{C}_{2} \mathrm{H}_{4} / \mathrm{C}_{2} \mathrm{H}_{6}$ ratio for coal and oil shale began to decrease rapidly, entering into the decline stage. When coal reached $160{ }^{\circ} \mathrm{C}$, oil shale reached $180{ }^{\circ} \mathrm{C}$, and the mixture reached $150{ }^{\circ} \mathrm{C}$, the curves for the three samples entered into the stable stage. The curve was stabilized at 0.3 for oil shale and the mixture, and at 0.22 for coal. According to the experiment, $\mathrm{C}_{2} \mathrm{H}_{4}$ and $\mathrm{C}_{2} \mathrm{H}_{6}$ are all gases produced by oxidation. The index of $\mathrm{C}_{2} \mathrm{H}_{4} / \mathrm{C}_{2} \mathrm{H}_{6}$ was defined as the ratio of the $\mathrm{C}_{2} \mathrm{H}_{4}$ content to the $\mathrm{C}_{2} \mathrm{H}_{6}$ content. This index was not available for the original coal seams. Using this index, the influence of the air volume and other factors could be eliminated. The curves of the three samples could be clearly divided into three stages. Therefore, the $\mathrm{C}_{2} \mathrm{H}_{4} / \mathrm{C}_{2} \mathrm{H}_{6}$ ratio could be used as an index to determine the temperature variations of coal and oil shale.

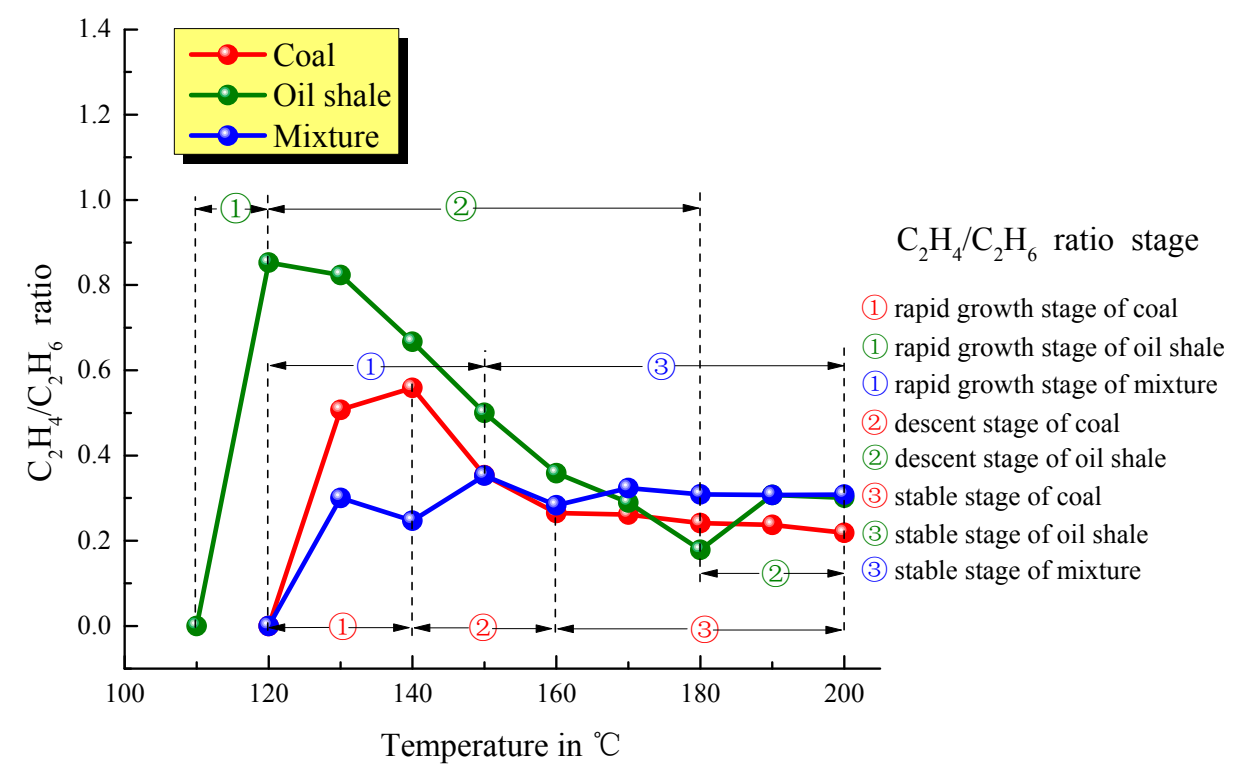

Figure 5. Relationship between the $\mathrm{C}_{2} \mathrm{H}_{4} / \mathrm{C}_{2} \mathrm{H}_{6}$ ratio and temperature for the experimental samples.

Table 5. Three sample stages divided according to the $\mathrm{C}_{2} \mathrm{H}_{4} / \mathrm{C}_{2} \mathrm{H}_{6}$ and $\mathrm{C}_{3} \mathrm{H}_{8} / \mathrm{C}_{2} \mathrm{H}_{6}$ ratios.

\begin{tabular}{ccccc}
\hline Index & Sample & Rapid Growth Stage $/{ }^{\circ} \mathbf{C}$ & Decline Stage $/{ }^{\circ} \mathbf{C}$ & Stable Stage $/{ }^{\circ} \mathbf{C}$ \\
\hline \multirow{2}{*}{$\mathrm{C}_{2} \mathrm{H}_{4} / \mathrm{C}_{2} \mathrm{H}_{6}$} & Coal & $120-140$ & $140-160$ & $160-200$ \\
& Oil shale & $110-120$ & $120-180$ & $180-200$ \\
& Mixture & $120-150$ & - & $150-200$ \\
\hline \multirow{2}{*}{$\mathrm{C}_{3} \mathrm{H}_{8} / \mathrm{C}_{2} \mathrm{H}_{6}$} & Coal & $120-140$ & $140-150$ & $150-200$ \\
& Oil shale & $120-140$ & $140-150$ & $150-200$ \\
& Mixture & $120-150$ & $160-160$ & $160-200$ \\
\hline
\end{tabular}


Figure 6 shows the variation of the $\mathrm{C}_{3} \mathrm{H}_{8} / \mathrm{C}_{2} \mathrm{H}_{6}$ ratio with temperature for the three samples. The $\mathrm{C}_{3} \mathrm{H}_{8} / \mathrm{C}_{2} \mathrm{H}_{6}$ ratio of the three samples first presented a rapid growth and then tended to be stable. Before $140{ }^{\circ} \mathrm{C}$, the ratios for the three samples were all at the rapid growth stage. At $140-150{ }^{\circ} \mathrm{C}$, the ratios of coal and oil shale were in the descent stage. However, there was a significant lag period (150-160 ${ }^{\circ} \mathrm{C}$ ) for the mixture at the descent stage. At this stage, the $\mathrm{C}_{3} \mathrm{H}_{8} / \mathrm{C}_{2} \mathrm{H}_{6}$ ratio of the oil shale and the mixture of coal and oil shale decreased similarly, but much less than that of coal. After $150{ }^{\circ} \mathrm{C}$, the ratio of coal tended to be stabilized at 0.62 , similar to that of the mixture. According to Table 5, the turning point values of the different stages can be obtained. Therefore, similar to the $\mathrm{C}_{2} \mathrm{H}_{4} / \mathrm{C}_{2} \mathrm{H}_{6}$ ratio, the $\mathrm{C}_{3} \mathrm{H}_{8} / \mathrm{C}_{2} \mathrm{H}_{6}$ ratio could also be used as an index to determine the oxidation of coal and oil shale.

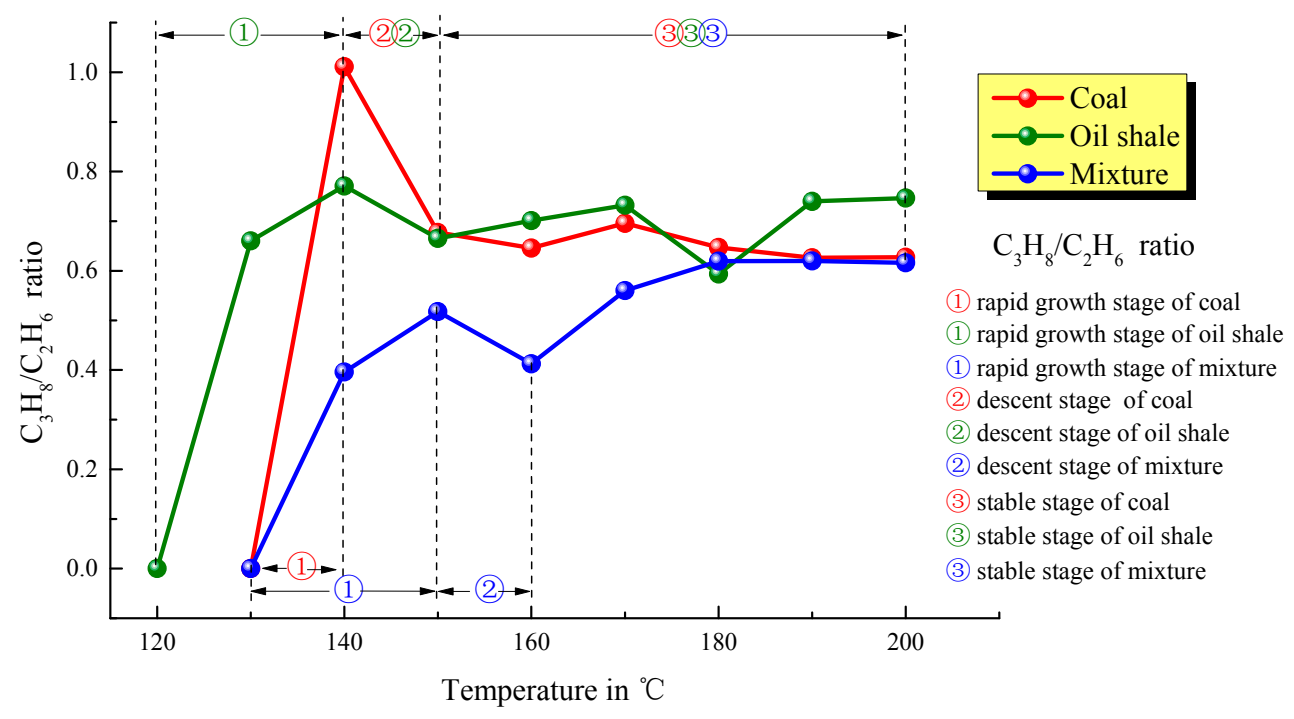

Figure 6. Relationship between the $\mathrm{C}_{3} \mathrm{H}_{8} / \mathrm{C}_{2} \mathrm{H}_{6}$ ratio and temperature for the experimental samples.

\section{Field Experiment}

\subsection{Introduction of the Field}

The Liangiia Coal Mine is located in Longkou City of Shandong Province in China, as shown in Figure 7. The 1105 working face was designed for mining the seam of Coal1 Oil shale2. The working seam had a thickness of 4.04 4.23 m, with an average of $4.15 \mathrm{~m}$. The upper layer, Coal1, had a simple structure, without or, occasionally, with a layer of gangue. This layer had a thickness $0.66 \sim 0.81 \mathrm{~m}$, with an average of $0.74 \mathrm{~m}$. The middle layer, Oil shale2 Upper2, had a thickness of $2.15 \sim 2.30 \mathrm{~m}$. with an average of $2.24 \mathrm{~m}$. The lower layer, Oil2 Upper1, had a thickness of $1.10 \sim 1.30 \mathrm{~m}$. with an average of $1.17 \mathrm{~m}$.

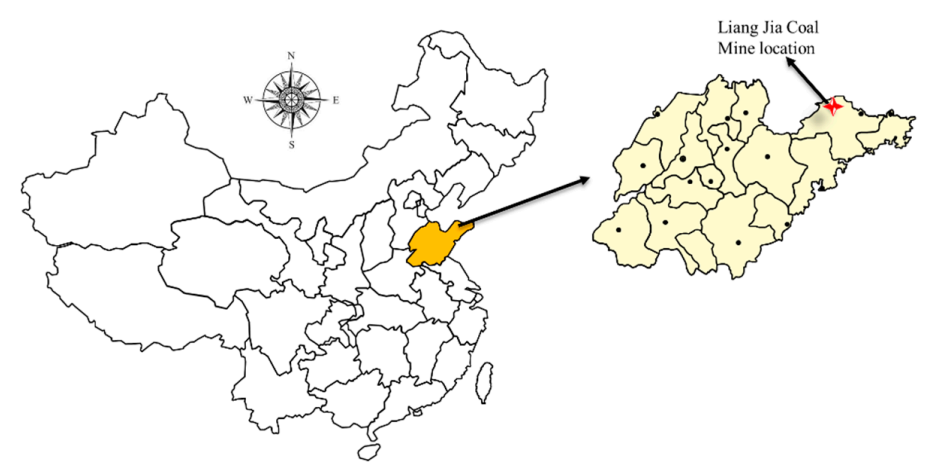

Figure 7. Location of the Liangjia Coal Mine. 
The roof of the 1105 working face contains oil-containing mudstones, which belong to mudstones with noncombustible, evenly distributed gray matter, and $13.28 \mathrm{~m}$ thick siltstones. The 1105 working face is a $1406.4 \mathrm{~m}$ long monoclinic structure in the mining direction with an average horizontal distance of $184.6 \mathrm{~m}$, average dip of $9^{\circ}$. It strikes NE and tends to SE. The whole working face is a co-mining face of coal and oil shale. Because of the limitations of the mining angle and the geological structure, residual oil shale was left in the goaf at the intake end of the co-mining working face, whereas in the middle of the working face, the amount of residual coal of coal1 increases progressively from the intake end to the return end, and, thus, there is a large amount of residual coal at the return end of the working face.

\subsection{Field Experiment}

The method of burying a beam tube monitoring system in the experimental field was adopted. In brief, after the temperature sensor and the beam tube were placed at the five measuring points of the working face, as the working face advanced, the temperature sensor and the beam tube would gradually be buried in the goaf. The protection of the outer steel pipe ensured the normal use of the beam tube and that the temperature measuring tube collected data at the airway. The air sample was extracted through the extraction pipes and sent to the gas chromatograph for analysis. The temperature variation in the goaf was measured by the buried temperature sensors. Figure 8 shows the layout of the measuring points for the 1105 working face.

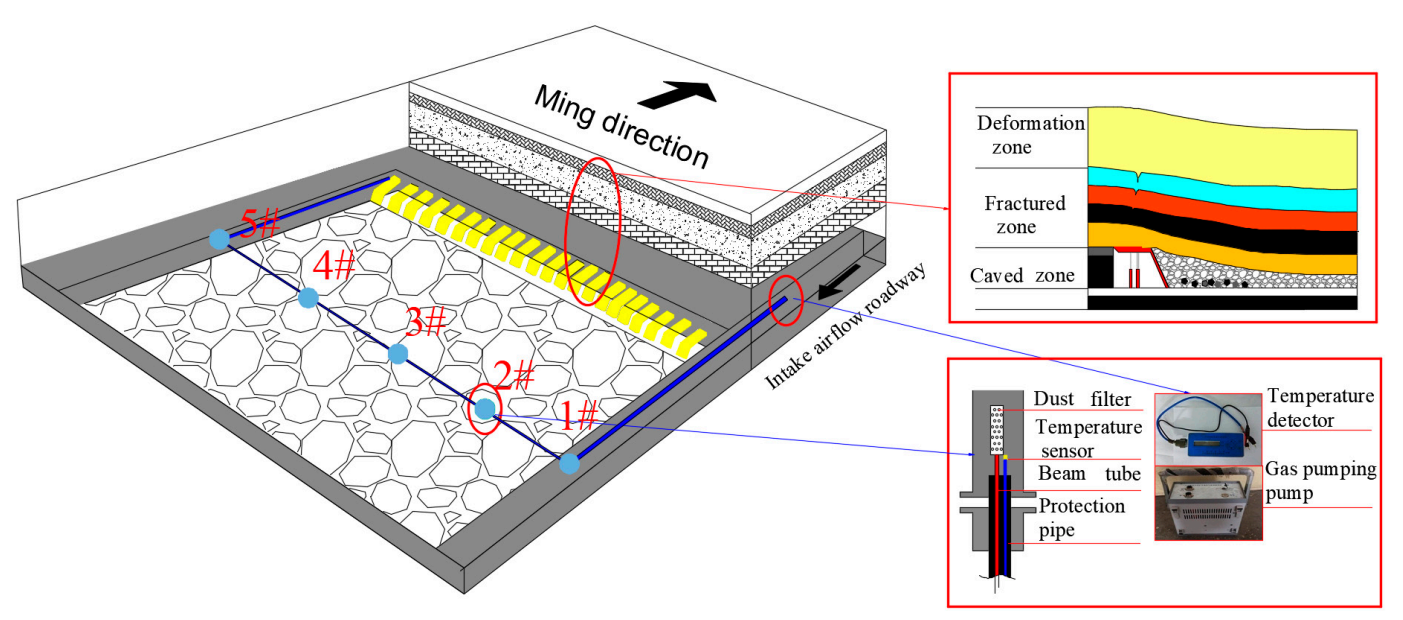

Figure 8. Schematic diagram of the 1105 working face measuring points.

According to the specific field conditions, five measuring points were equidistantly spaced from the air intake end to the return end. Among them, three were arranged in the central part and the other two were arranged at the inlet and outlet of the airway, respectively. The locations of the five measuring points were as follows: \#1 measuring point was set at the junction of the intake airway and the working face to monitor oil shale; \#2, \#3, \#4 measuring points were located in the middle of the goaf to measure the mixture of coal and oil shale; \#5 measuring point was set at the junction of the return airway of the working face to monitor coal.

\subsection{Analysis of the Experimental Data}

Because the temperature measurement wire and beam tube of the \#3 measuring point were damaged during the transfer of the hydraulic support, data from \#1, \#2, \#4, and \#5 measuring points were collected and analyzed. The curve, as shown in Figure 9, was made according to the available experimental data. When the measuring points were $95.2 \mathrm{~m}$ from the working face, the temperature values at these measuring points in the goaf showed a significant decline process and the gases tended 
to be stable. In this paper, the low-temperature oxidation law of coal and oil shale was studied to determine the variation of the behaviors of high temperature zones and gas concentration in the goaf. Therefore, data collection was stopped after $95.2 \mathrm{~m}$.

The overview of the temperature distribution in the goaf is shown in Table 6. Figure 10 displays the measured temperature results across the working face in a three-dimensional color-coded surface plot of temperature through time and distance from the working face.

Table 6. Overview of the temperature distribution in the goaf.

\begin{tabular}{ccccc}
\hline $\begin{array}{c}\text { Measuring } \\
\text { Point }\end{array}$ & $\begin{array}{c}\text { Initial } \\
\text { Temp }\left({ }^{\circ} \mathbf{C}\right)\end{array}$ & $\begin{array}{c}\text { Highest } \\
\text { Temp }\left({ }^{\circ} \mathbf{C}\right)\end{array}$ & $\begin{array}{c}\text { Amplitude of } \\
\text { Temp Rise }\left({ }^{\circ} \mathbf{C}\right)\end{array}$ & $\begin{array}{c}\text { Distance of Highest Temp Location } \\
\text { from the Working Face }(\mathbf{m})\end{array}$ \\
\hline 1\# & 21.6 & 29.4 & 7.8 & 80.8 \\
$2 \#$ & 25 & 35.2 & 10.2 & 77.2 \\
$4 \#$ & 25.1 & 34.1 & 9 & 73.6 \\
$5 \#$ & 26.4 & 37.8 & 11.4 & 77.2 \\
\hline
\end{tabular}

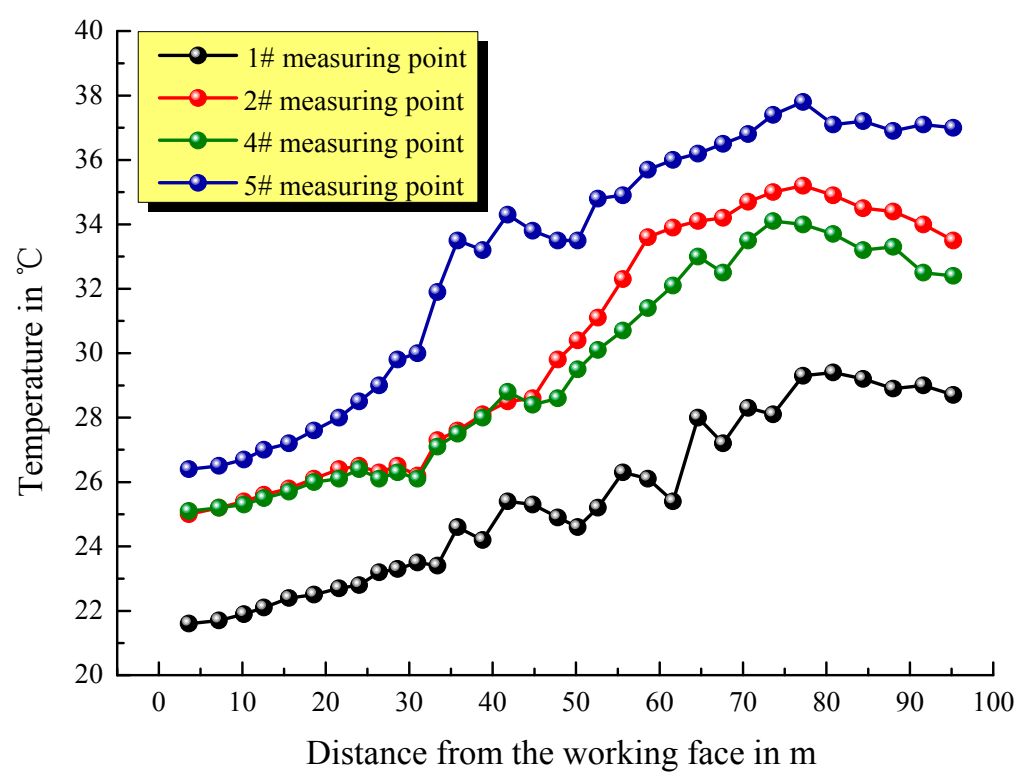

Figure 9. Temperature curve for $\# 1, \# 2, \# 4$, \#5 measuring points.

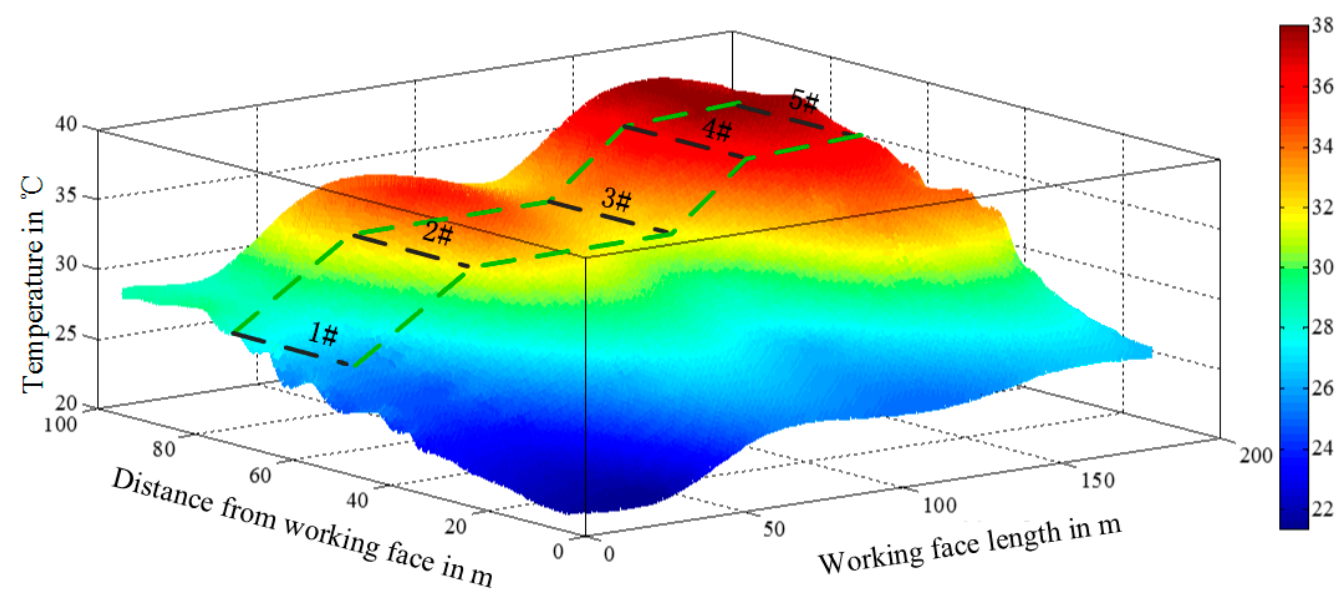

Figure 10. Cloud picture of the actual temperatures in the goaf. 
In the initial measurement, the starting temperature was the highest at the \#5 measuring point for coal and the lowest at the \#1 measuring point for oil shale. This may be due to the fact that the air flowing through the work surface brought the heat from the coal seam into the return airway, increasing the temperature at the \#5 measuring point. However, with the advancement of the working face, the effects of the temperature of the fresh airflow and the initial temperature of coal and rock mass on the temperature of the goaf gradually decreased. Thus, the temperature rise in the goaf can be regarded as the heat released by the oxidation of coal and rock mass. In order to study the oxidation heat release behaviors of coal, oil shale, and their mixture, the amplitude of the temperature rise at each measuring point was analyzed to determine the amount of heat release. In the range of $31 \mathrm{~m}$ from the working face, the porosity was high since the collapse material in the goaf was not compacted, and air leakage took away part of the heat, so that an effective heat storage environment could not be formed, resulting in a slow temperature rise for various measuring points in the goaf. When the distance from the working face exceeded $31 \mathrm{~m}$, the temperature increased rapidly, and the amplitude of the temperature rise at the \#5 measuring point for coal was the largest, with the temperature rise rate higher than that at the measuring points for mixture and oil shale. The measuring point for oil shale had the smallest temperature rising rate with minimal heat release. The heat release from the mixture was between those from coal and oil shale. The temperatures at the mixture measuring points $\# 2$ and \#4 were basically the same before $45 \mathrm{~m}$. After $45 \mathrm{~m}$, the \#2 temperature measuring point near oil shale slightly exceeded the \#4 measuring point near coal. Our analysis suggested that oil shale may slightly promote the cooling of coal and played a catalyst role. During the measurement, the coal measuring point had the highest amount of heat release and the highest temperature point of $37.8^{\circ} \mathrm{C}$ in the goaf. The high-temperature area was $77-80 \mathrm{~m}$ away from the working face in the whole goaf. The temperature was the highest for the residual coal points, followed by the mixture points of coal and oil shale, and the lowest for the oil shale points. Therefore, the temperature in the goaf gradually increased from the end of the oil shale to the coal sample and showed a ladder-like distribution.

Figure 11 shows the relationship of $\mathrm{CO}$ concentration to the distance. For the first detection, $\mathrm{CO}$ was already detected at the measuring points for coal and the mixture, but not for oil shale. With the advance of the working face, $\mathrm{CO}$ concentration increased rapidly for coal and the mixture, reaching the peak values of: $36.00 \mathrm{ppm}$ at $\# 2$ measuring point which was $64.6 \mathrm{~m}$ away from the working face; $44.00 \mathrm{ppm}$ at $\# 4$ measuring point which was $73.6 \mathrm{~m}$ away from the working face; $80.00 \mathrm{ppm}$ at \#5 measuring point, which was $70.6 \mathrm{~m}$ away from the working face. The higher the amount of the remaining coal, the higher the CO peaks. CO was basically not detected for oil shale with only occasional $\mathrm{CO}$ fluctuations. Considering the finding from the programmed heating experiment that no $\mathrm{CO}$ was produced from oil shale by oxidation below $40^{\circ} \mathrm{C}$, it is speculated that $\mathrm{CO}$ came from other locations to the oil shale measuring points because of the airflow in the goaf. For the mixture sample in the goaf, when the distance was $>65 \mathrm{~m}, \mathrm{CO}$ concentration was obviously higher at the \#4 measuring point than at the \#2 measuring point. This was probably due to the fact that the \#4 measuring point was closer to the coal and contained a larger proportion of coal in the mixture, therefore producing more CO. A high concentration of CO was mainly detected in the area from $61.6 \mathrm{~m}$ to $80.8 \mathrm{~m}$ from the working face in the goaf. For the peak values, $\mathrm{CO}$ concentration was the highest at the measuring points for coal and the lowest at the measuring points for the mixture. 


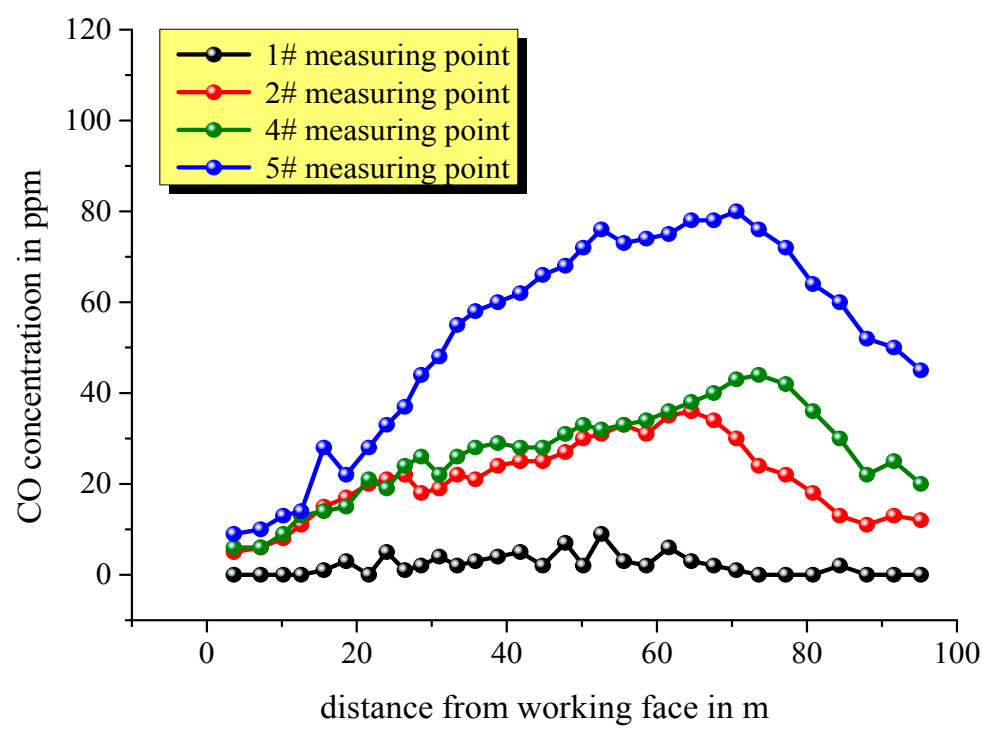

Figure 11. CO concentration for $\# 1, \# 2, \# 4, \# 5$ measuring points.

\section{Discussion}

In this paper, the 1105 co-mining face of coal and oil shale at the Liangjia Coal Mine in Shandong Province of China was chosen as the object to study, and the low-temperature oxidation laws of coal and oil shale were obtained by comparing the results from the laboratory programmed heating experiments and the actual field measurements.

When the selected coal and oil shale samples were at the initial low-temperature oxidation stage in the programmed heating experiment, the three tested samples were all at a slow oxidation stage, with the temperature rise rate lower than that set in the programmed heating experiment, and their temperatures were lower than the oven temperature. The amount of heat released from oil shale was less than that from coal at the initial oxidation stage. Since different coal mines have different ambient thermal states, ventilation, mining time, and coal and oil shale properties, as well as rubbles with different porosity and permeability in the goaf, we chose the co-mining face of coal and oil shale at the Liangjia Coal Mine as the research object. Through the field beam tube monitoring system in the goaf, it was found that the temperature at various measuring points never exceeded $38^{\circ} \mathrm{C}$, which corresponds to the low-temperature oxidation in the programmed heating experiment. Among the five measuring points, the temperature was the lowest at the \#1 measuring point and the highest at the \#5 measuring point. This was because coal content was the lowest at the \#1 measuring point, higher at the $\# 2$ and \#4 measuring points, and the highest at the \#5 measuring point. The initial temperatures from field monitoring are consistent with those from the programmed heating experiment. According to the programmed heating experiment, it was found that, when the ambient temperature exceeded $85{ }^{\circ} \mathrm{C}$, the acceleration of the temperature rise rate increased and the cross-point temperature was reached for oil shale, followed by the mixture and then coal, and the final temperature was the highest for oil shale, followed by coal, and the lowest for the mixture, indicating that at the end of the low-temperature oxidation, if cooling measures were not taken timely for the goaf of the co-mining face of coal and oil shale, the temperature of oil shale would rapidly increase and reach the highest temperature, easily leading to goaf fires. The fire risk is the second highest for coal and the lowest for mixed coal and oil shale because there is a slight mutual suppression effect on heat liberation in mixed coal and oil shale.

According to the programmed heating experiment, it was found that there were three stages for both gas concentrations and their ratios. For $\mathrm{CO}$, the slow growth phase of the three samples was the same. However, the coal sample had a lower initial CO producing temperature than the oil shale sample, and produced the highest amount of $\mathrm{CO}$. The oil shale had the highest initial CO producing temperature. The concentration of $\mathrm{CO}$ produced by the mixture of coal and oil shale was the lowest, 
with an average of $38 \%$ of that produced by coal, because of the suppression effect of the mixture on $\mathrm{CO}$ production. These results combined with those obtained from the field beam tube monitoring system, indicated that the residual coal was the main component at the \#5 measuring point, and thus, at this point, $\mathrm{CO}$ was produced first, and its concentration increased rapidly and was the highest in the goaf. Oil shale was the main component at the \#1 measuring point, and at this point $\mathrm{CO}$ was not produced because the temperature did not reach the $\mathrm{CO}$ production temperature point. There was a slight $\mathrm{CO}$ fluctuation due to the airflow distribution in the goaf. Mixed coal and oil shale were the main components at \#2 and \#4 measuring points. At these points, the average $\mathrm{CO}$ concentration was only $46 \%$ of that at the measuring points for coal because of the mutual inhibiting effect of coal and oil shale on CO production.

Based on the concentration ratio of various gases, several critical temperature points could be determined. As shown in Tables 3-5, a rapid increase of the $\mathrm{CO} / \mathrm{CO}_{2}$ ratio indicated that the oxidation temperature for oil shale, mixture, and coal had reached $80^{\circ} \mathrm{C}, 90^{\circ} \mathrm{C}, 40^{\circ} \mathrm{C}$ or $100{ }^{\circ} \mathrm{C}$, respectively. When the temperature exceeded $110{ }^{\circ} \mathrm{C}$, the $\mathrm{C}_{2} \mathrm{H}_{4} / \mathrm{C}_{2} \mathrm{H}_{6}$ ratio for oil shale presented a rapid growth and, at $120^{\circ} \mathrm{C}$, it showed a decline trend. When the $\mathrm{C}_{3} \mathrm{H}_{8} / \mathrm{C}_{2} \mathrm{H}_{6}$ ratio increased rapidly, coal, oil shale, and mixture had reached $120^{\circ} \mathrm{C}$. At $140{ }^{\circ} \mathrm{C}$, the ratios of $\mathrm{C}_{3} \mathrm{H}_{8} / \mathrm{C}_{2} \mathrm{H}_{6}$ of coal and oil shale declined at the same time. The small fluctuation of the $\mathrm{C}_{3} \mathrm{H}_{8} / \mathrm{C}_{2} \mathrm{H}_{6}$ curve suggested that coal and oil shale had both reached $150{ }^{\circ} \mathrm{C}$. When, above $160{ }^{\circ} \mathrm{C}$, the $\mathrm{CO} / \mathrm{CO}_{2}$ ratio of coal changed from rapid growth to slow growth, at the same time the $\mathrm{C}_{2} \mathrm{H}_{4} / \mathrm{C}_{2} \mathrm{H}_{6}$ curve had been almost stable, and the $\mathrm{C}_{3} \mathrm{H}_{8} / \mathrm{C}_{2} \mathrm{H}_{6}$ ratio of the mixture tended to be stable. The $\mathrm{CO}$ curve and the $\mathrm{CO} / \mathrm{CO}_{2}$ curve for oil shale changed from rapid growth to slow growth at $160{ }^{\circ} \mathrm{C}$ and $170{ }^{\circ} \mathrm{C}$, respectively. At $180{ }^{\circ} \mathrm{C}$, the $\mathrm{C}_{2} \mathrm{H}_{4} / \mathrm{C}_{2} \mathrm{H}_{6}$ curve slowed the decline trend, entering the stable stage. After the mixture of coal and oil shale reached $190^{\circ} \mathrm{C}$, the growth rate of the $\mathrm{CO} / \mathrm{CO}_{2}$ ratio decreased, with a transition from fast growth to slow growth.

\section{Conclusions}

The programmed heating experiment showed that when coal was at the initial stage of low-temperature oxidation, the amount of heat release was mostly from coal, followed by the mixture of coal and oil shale, and then by oil shale. The field experiment showed that the temperature field in the goaf of a co-mining face of coal and oil shale had, generally, a ladder-like distribution, and that the temperature was the highest for the residual coal followed by the mixture, and the lowest for oil shale. If there was a continuous thermal storage environment in the goaf, heat release was mainly from oil shale; and at high ambient temperature, heat release was basically the same for the mixture and coal. According to the programmed heating experiment, if no measures were taken, there would be high temperature points at the location of oil shale.

The CO concentration in the goaf at the time of co-mining of coal and oil shale was analyzed. $\mathrm{CO}$ was first produced at the place of residual coal in the goaf with the highest concentration, and oil shale had a high CO generation temperature. When coal was mixed with oil shale, $\mathrm{CO}$ was first produced from the coal in the mixture. However, mixing coal and oil shale eventually inhibited CO production from both. Actually, the field measurements showed that the average $\mathrm{CO}$ concentration at the measuring points for the mixture of coal and oil shale was $46 \%$ of that for coal. This inhibition of $\mathrm{CO}$ production was more significant beyond the point of initiation of rapid heating and $\mathrm{CO}$ generation, when control becomes difficult.

The gas compositions during low-temperature oxidation of coal, oil shale, and mixture were analyzed based on the programmed heating experiment. The curves of the indexes, namely, $\mathrm{CO}$, $\mathrm{CO} / \mathrm{CO}_{2}, \mathrm{C}_{2} \mathrm{H}_{4} / \mathrm{C}_{2} \mathrm{H}_{6}$ and $\mathrm{C}_{3} \mathrm{H}_{8} / \mathrm{C}_{2} \mathrm{H}_{6}$, were analyzed and divided into different stages, and the turning points of each index were determined. According to those turning points, the oxidation stages of coal and oil shale were established. 
In this study, we only investigated the face of the Liangjia Coal Mine in China. In goafs with different geological conditions and different coal-to-oil shale stoichiometry, the characteristics of the oxidation and the interaction mechanisms between coal and oil shale need to be further explored.

Acknowledgments: The work presented in this paper was supported by the National Key Research and Development Program of China (Project No. 2017YFC0805201), the National Natural Science Foundation of China (Project No. 51674158), the Taishan Scholar Talent Team Support Plan for Advantaged \& Unique Discipline Areas, the Source Innovation Program (Applied Research Special-Youth Special) of Qingdao (Project No. 17-1-1-38-jch), the Open Fund of Hebei State Key Laboratory of Mine Disaster Prevention (Project No.KJZH2017K10), and the Shandong University of Science and Technology Research Fund (Project No. 2015JQJH105). In addition, thanks are due to related people at the Liangjia coal mine in China. It is because of their support, that the work described in this paper could be successfully completed.

Author Contributions: Gang Wang and Yue Wang conducted the main work and wrote the paper; Lulu Sun took part in laboratory experiments and designed the field tests; Xiang Song and Qiqi Liu carried out laboratory experiments; Hao $\mathrm{Xu}$ and Wenzhou Du finished the field experiment and the related data analysis. They all provided insightful suggestions and revised the paper.

Conflicts of Interest: The authors declare no conflict of interest. The founding sponsors had no role in the design of the study; in the collection, analyses, or interpretation of the data; in the writing of the manuscript, and in the decision to publish the results.

\section{References}

1. Liang, Y.-T.; Luo, H. Current situation and development trend for coal mine fire prevention \& extinguishing techniques in China. J. China Coal Soc. 2008, 33, 126-130.

2. Song, J.; Littke, R.; Weniger, P.; Ostertag-Henning, C.; Nelskamp, S. Shale oil potential and thermal maturity of the lower toarcian posidonia shale in NW Europe. Int. J. Coal Geol. 2015, 150, 127-153. [CrossRef]

3. Aboulkas, A.; El Harfi, K. Study of the kinetics and mechanisms of thermal decomposition of Moroccan Tarfaya oil shale and its kerogen. Oil Shale 2008, 25, 426-443. [CrossRef]

4. Dyni, J.R. Geology and resources of some world oil-shale deposits. Oil Shale 2003, 20, 193-253.

5. Wang, Q.; Sun, B.; Liu, H.; Bai, J.; Xiao, G. Analysis of mineral behavior during pyrolysis of oil shale. J. Fuel Chem. Technol. 2013, 41, 163-168.

6. Jiang, H.; Deng, S.; Chen, J.; Zhang, M.; Li, S.; Shao, Y.; Yang, J.; Li, J. Effect of hydrothermal pretreatment on product distribution and characteristics of oil produced by the pyrolysis of Huadian oil shale. Energy Conver. Manag. 2017, 143, 505-512. [CrossRef]

7. Al-Harahsheh, M.; Al-Ayed, O.; Robinson, J.; Kingman, S.; Al-Harahsheh, A.; Tarawneh, K.; Saeid, A.; Barranco, R. Effect of demineralization and heating rate on the pyrolysis kinetics of Jordanian oil shales. Fuel Process. Technol. 2011, 92, 1805-1811. [CrossRef]

8. Miao, Z.; Wu, G.; Li, P.; Meng, X.; Zheng, Z. Investigation into co-pyrolysis characteristics of oil shale and coal. Int. J. Mining Sci. Technol. 2012, 22, 245-249. [CrossRef]

9. Tuğluhan, A.M.; Mehmetoğlu, M.T.; Bağc1, S. Oxidation kinetics of a Turkish oil shale. Fuel Process. Technol. 1991, 29, 231-240. [CrossRef]

10. Li, S.; Ma, X.; Liu, G.; Guo, M. A TG-FTIR investigation to the co-pyrolysis of oil shale with coal. J. Anal. Appl. Pyrolysis 2016, 120, 540-548. [CrossRef]

11. Lu, P.; Liao, G.; Sun, J.; Li, P. Experimental research on index gas of the coal spontaneous at low-temperature stage. J. Loss Prev. Process. Ind. 2004, 17, 243-247. [CrossRef]

12. Zhang, X.-H.; Wen, H.; Deng, J.; Zhang, X.-C.; Tien, J.C. Forecast of coal spontaneous combustion with artificial neural network model based on testing and monitoring gas indices. J. Coal Sci. Eng. 2011, 17, 336-339. [CrossRef]

13. Ogunsola, O.I.; Mikula, R.J. A study of spontaneous combustion characteristics of Nigerian coals. Fuel 1991, 70, 258-261. [CrossRef]

14. Chen, X.; Chong, L. Several important issues related to the crossing-point temperature (CPT) method for measuring self-ignition kinetics of combustible solids. Process. Saf. Environ. Prot. 1998, 76, 90-93. [CrossRef]

15. Qin, Y.; Liu, W.; Yang, C.; Fan, Z.; Wang, L.; Jia, G. Experimental study on oxygen consumption rate of residual coal in goaf. Saf. Sci. 2012, 50, 787-791. [CrossRef] 
16. Küçük, A.; Kadığlu, Y.; Gülaboğlu, M. A study of spontaneous combustion characteristics of a Turkish lignite: Particle size, moisture of coal, humidity of air. Combust. Flame 2003, 133, 255-261. [CrossRef]

17. Tan, B.; Li, H.; Gao, P.; Li, K. Temperature-programmed experimental study on stage characteristics of coal spontaneous combustion disaster gas indicators. Zhongguo Anquan Kexue Xuebao 2013, 23, 51-57.

18. Perera, M.S.A.; Ranjith, P.G.; Choi, S.K.; Bouazza, A.; Kodikara, J.; Airey, D. A review of coal properties pertinent to carbon dioxide sequestration in coal seams: With special reference to Victorian brown coals. Environ. Earth Sci. 2011, 64, 223-235. [CrossRef]

19. Masoudian, M.S.; Airey, D.W.; El-Zein, A. Mechanical and flow behaviours and their interactions in coalbed geosequestration of $\mathrm{CO}_{2}$. Geomech. Geoengin. 2013, 8, 229-243. [CrossRef]

20. Connell, L.D.; Detournay, C. Coupled flow and geomechanical processes during enhanced coal seam methane recovery through $\mathrm{CO}_{2}$ sequestration. Int. J. Coal Geol. 2009, 77, 222-233. [CrossRef]

21. Wold, M.B.; Connell, L.D.; Choi, S.K. The role of spatial variability in coal seam parameters on gas outburst behaviour during coal mining. Int. J. Coal Geol. 2008, 75, 1-14. [CrossRef]

22. Masoudian, M.S.; Airey, D.W.; El-Zein, A. The role of coal seam properties on coupled processes during $\mathrm{CO}_{2}$ sequestration: A parametric study. Greenh. Gases Sci. Technol. 2016, 6, 492-518. [CrossRef]

23. Xie, Z.; Cai, J.; Zhang, Y. Division of spontaneous combustion "three-zone" in goaf of fully mechanized coal face with big dip and hard roof. Procedia Eng. 2012, 43, 82-87. [CrossRef]

24. Rong-kun, P.; Chang, L.; Ke, Y.; Ming-gao, Y. Distribution regularity and numerical simulation study on the coal spontaneous combustion "three zones" under the ventilation type of ventilation type of $\mathrm{Y}+\mathrm{J}$. Procedia Eng. 2011, 26, 704-711. [CrossRef]

25. Pan, R.; Cheng, Y.; Yu, M.; Lu, C.; Yang, K. New technological partition for "three zones" spontaneous coal combustion in goaf. Int. J. Min. Sci. Technol. 2013, 23, 489-493. [CrossRef]

26. Wang, H.; Dlugogorski, B.Z.; Kennedy, E.M. Coal oxidation at low temperatures: Oxygen consumption, oxidation products, reaction mechanism and kinetic modelling. Prog. Energy Combust. Sci. 2003, 29, 487-513. [CrossRef]

27. Cliff, D.; Brady, D.; Watkinson, M. Spontaneous Combustion in Australian Coal Mines; Simtars: Redbank, Australia, 2015.

28. Jun, D.; Jingyu, Z.; Yanni, Z.; Ruilin, G. Study on coal spontaneous combustion characteristic temperature of growth rate analysis. Procedia Eng. 2014, 84, 796-805. [CrossRef]

29. Su, H.; Zhou, F.; Li, J.; Qi, H. Effects of oxygen supply on low-temperature oxidation of coal: A case study of Jurassic coal in Yima, China. Fuel 2017, 202, 446-454. [CrossRef]

30. Xuyao, Q.; Wang, D.; Milke, J.A.; Zhong, X. Crossing point temperature of coal. Min. Sci. Technol. 2011, 21, 255-260. [CrossRef]

(C) 2018 by the authors. Licensee MDPI, Basel, Switzerland. This article is an open access article distributed under the terms and conditions of the Creative Commons Attribution (CC BY) license (http://creativecommons.org/licenses/by/4.0/). 